\title{
Ana's tragedy - and Europe's a contemplation over Romani, belonging and the conditioned citizenship making in a Europe of migration
}

\author{
Magnus Dahlstedt ${ }^{1} \cdot$ Maria Olson $^{2,3,4}$ iD
}

Received: 10 September 2016 / Accepted: 18 November 2016/Published online: 29 November 2016

(C) The Author(s) 2016. This article is published with open access at Springerlink.com

\begin{abstract}
This article deals with the notion of belonging in today's multi-ethnic Sweden and hints at perpectives of future European identity-building. On the basis of Frantz Fanon's understanding of colonialism and the colonized mentality as theoretical, the article deals with the situation of Roma in Sweden - and Europe. With the story of a young Roma woman that has migrated to Sweden from Hungary as point of departure, the article addresses the situation for Romani people, but also for other migrants in Europe, with particular focus on who are allowed to belong to the community of Swedish and European citizens, and who are not.
\end{abstract}

Keywords Belonging $\cdot$ Migration $\cdot$ Roma $\cdot$ Society $\cdot$ Sweden $\cdot$ Europe

\section{Introduction}

"It is on that other being, on recognition by that other being, that his own human worth and reality depend. It

Maria Olson

maol@du.se

Magnus Dahlstedt

magnus.dahlstedt@liu.se

1 Department of Social and Welfare Studies/Division Social Work, Linköping University, S-601 74 Norrköping, Sweden

2 School of Education, Health and Society, Dalarna University, S-791 88 Falun, Sweden

3 Stockholm University, Stockholm, Sweden

4 University of Skövde, Skövde, Sweden is that other being in whom the meaning of his life is condensed." [1: 169]

Since 2015, more than a million people have been seeking refuge in Europe. Most of them have come from the war-torn Syria. Throughout the member states of the European Union, among these also Sweden, exceptional policy measures are being taken in order to handle the so-called "refugee crisis" - intensified border control, the introduction of identity checks at specific checkpoints as well as within the borders of a country, and restrictive rules for the reception of asylum seekers, to mention but some of these measures. This precarious situation addresses a number of crucial questions about belonging in an age of large-scale international migration where established conceptions of who belongs to the society, and who do not, are challenged: who is actually included in society? Who is excluded? And out of what principles are the borders and boundaries for this inclusion and exclusion drawn? In the wake of the so-called "refugee crisis", all of these questions are at the very centre of the political debate in Europe.

Taking on the story of Ana, a Roma woman that has migrated to Sweden, we want to make visible that the tragedy of Ana's mirrors the scope of Europe as a site for migration in the present multicultural situation, and vice versa. Through these connecting points in Ana's and Europe's situation, we wish to illustrate and discuss some of the personal as well as societal tensions and challenges in terms of citizenship and citizenship formation in Europe of today, in an era of international migration.

More concretely, our points emerging from Ana's struggle in trying to come to terms with the migrant situation in which she finds herself, aiming at becoming part of a Swedish society, represents a story of belonging but simultaneously not belonging to this society. It is the paradox involved in this process, which itself is intricate because she is a Roma, that 
further illustrates the very paralysis at work in the (efforts made for) inclusion and citizenship in times of migration in Europe. As a Roma she personifies the ideal EU citizen, which is flexible, allegedly mobile and non-territorial by definition. At the same time, though, she becomes an anomaly to this ideal EU citizen on her own command [1-3]. Thus, the struggles and challenges visible in Ana's story could be used as a starting point in order to also make on-going struggles and challenges in terms of European citizenship visible, pointing in different directions of the future of Europe.

We argue that the current refugee situation in Europe sheds light on a deeper friction in the European self-image. What is at stake is, more precisely, that what is currently described in terms of "refugee crisis" is not the crisis of the refugees, but that of Europe's. It is this particular friction that becomes visible in focusing on the situation of the Romani in the current Swedish and, further, the situation of Europe - as this situation challenges, as it has always challenged, common depictions of belonging in society, citizenship, that have more or less been taken-for-granted.

\section{Ana's story}

Ana was born in Hungary. Her father is Roma and her mother Hungarian. She came to Sweden with her family when she was 12 years old. Ana has since many years back Swedish citizenship, but sees herself still not really Swedish. "I'm Swedish, so to speak, I became a Swedish citizen by coming here [to Sweden]." When Ana describes herself and her membership of the Swedish society she emphasizes that there is a difference between her, with the background she has, and other Swedish nationals who were born in Sweden with native Swedish parents. She describes her affiliation to the society as a difficult balancing act, which is to find a balance between the "Hungarian", "Roma" and "Swedish":

"It's been difficult for me if I should be honest and decide, okay, I'll be Swedish, Hungarian or Roma, or how I like to get it together ... because you have Roma blood and Hungarian blood and so. Moreover, you live in Sweden. So it's hard to get it to actually go together."

When Ana tells about her life, it seems to be a fragmented existence, which is based on the fact that her background is difficult to reconcile with the fact that she now lives in Sweden. Her story is portrayed on the basis of a biological metaphor - Hungarian and Romani blood - on the basis of which affiliation that can be understood as a matter of biological origin. Based on such metaphors migration itself seems to be something problematic, because it involves the circumscription that people basically are understood as naturally resident in certain places, certain related communities, sharing certain values [4].

Taking on the case of Ana's, this stresses the difficulties for her to avoid or set aside that she has Roma and Hungarian blood, but not Swedish. And that she indeed lives in Sweden, but is not born into "Swedishness" [5]. When the various belongings should be weighed against each other, it is, however, clear from Ana's story in what manner they are weighted. It's between the Hungarian and the Swedish that a balance must be found. The Roma enters constantly in the background. This situation leaves us with the picture that Ana is Roma, but do not see herself as a Roma. This pattern that emerges in Ana's story is part of a larger historical pattern, we argue, where the Roma systematically have been put in the background.

\section{The Romani - Europe's other}

Roma have a long history in Sweden, capsized by persecution and repression. Turning to Sweden, there is for example systematically collected information on groups of travelers from the 1500 s onwards, categorized as gypsies or so called "tattare" [tatars]. These groups of travelers were seen as alien elements, sometimes described as exotic, but usually more or less menacing groups outside mainstream society [6].

Over time deep-rooted myths were established, in Sweden as well as in Europe, about these foreign elements, their appearance, background and way of life. According to the stereotype, they were often described as dark or black-skinned, dark-haired, brown-eyed, labor reluctant, dishonest, sneaky, wasteful and temperamental [7]. In brief, they have been a more or less non-adaptive threat to the existing order. Their existence in Europe has in many respects been a dark back the Others - against which the enlightened European civilization has taken shape. Interestingly, the anti-Semitism and racist anti-Roman positions remaining legacy. These "internal" figures of European otherness are, put differently, the continued form of both European identity that emanates out of the construction and consolidation of European national identities, and different postcolonial constellations of race [8].

\section{Fanon and the "colonial situation"}

In a similar way, Franz Fanon in his landmark book Black Skin, White Masks in 1952 described how the white Europe has reflected itself in the dark Africa. Europe has, according to him, emerged as civilized and developed precisely in contrast to the barbaric and underdeveloped Africa.

In Europe, whether concretely or symbolically, the black man stands for the bad side of the character. As long as 
one cannot understand this fact, one is doomed to talk in circles about the "black problem". Blackness, darkness, shadow, shades, night, the labyrinths of the earth, abysmal depths, blacken someone's reputation; and, on the other side the bright look of innocence, the white dove of peace, magical, heavenly light.[1:146]

Taking on Fanon's words, it is no coincidence that the Roma according to this stereotype are described as black or dark. The Romani can, more precisely, be seen as Europe's Negroes, a dark, alien population elements - socially, culturally or racially - one that different agents have tried to restrain and keep in place. Correspondingly, in relation to citizenship, the Romani have - in Sweden as in other European countries been regarded and treated as non-citizens, with other rights, obligations and substantial living conditions than the rest of society $[1,9]$. Therefore Fanon's theoretical outlining of the negro is helpful in understanding colonialism, the colonial fantasy world and the colonized mentality that the Roma activates again and again in Europe.

Further, Fanon argues, that the colonial racist understanding of the world that developed in the current assumedly colonial situation at that time meant a kind of mental straitjacket for the colonized: "Willy-nilly, the Negro has to wear on the livery that the white man has sewed for him." [1:22] With constant repetition, the usual stereotypes about the different and inferior "negro" eventually converted into the colonized self-image. Deep down, the colonized want to "civilize" themselves by becoming white - and thus annihilate themselves as black: "The colonized is elevated above his jungle status in proportion to his adoption of the mother country's cultural standards. He becomes whiter as he renounces his blackness, his jungle." [1:9]

To the aim of this article, the question that rises out of Fanon's ideas is which tracks that Europe's "colonial situation" have set out in relation to the Romani and their thinking about themselves in relation to the European society. It is precisely this problem that stands in the foreground and that will continue to follow in Ana's story about her meeting with Sweden and how she relates to her Roma identity. Before focusing on this meeting, a brief historical overview over the ways of the encounters with Roma in Sweden and in Europe is provided below.

\section{The Roma - Swedish and European histories}

During the 1600 s and 1700 s, a series of regulations specifically targeted at the travelers, which were intended to keep them out of the borders, or - for those who, after all, spent within the borders - forcing them to become permanent residents and work were introduced in Sweden. In addition, already in 1637 the death penalty for male Gypsies who did not voluntarily leave the country were introduced [7]. Towards the end of the $1800 \mathrm{~s}$, there was a comprehensive discussion proposing a series of coercive measures of forcibly assimilating the travelers, including taking care of children traveling [3]. With large-scale disposal it was envisaged that the travelers would automatically become permanent residents and eventually "brought up to decent and industrious citizens." [7]

Around the turn of the century there was a lively debate about immigration and the need to limit immigration to Sweden [6]. The starting point was a purity ideal: the Swedes were a people, a race, a culture, resident in one location. Immigration and Roma in particular hereby constitute an anomaly. This debate resulted in the introduction of a number of restrictions in the 1914 Aliens Act, including a total ban on Gypsy immigration - all Gypsies who lived in the country would be rejected by the police. The ban was extended in 1927 and 1937, and in 1945 immigration law were applied in practice until 1954. Gypsies fleeing Nazi violence were seeking refuge in the countries where they were welcome. But even though Sweden was an assumedly "neutral" nation state in the Second World War II, the ban was motivated partly due race biological motives: it was considered necessary because the Gypsies were simply not considered possible to be incorporated into Swedish society [10].

To come to terms with the problem that the travelers who were staying within the country required the adoption of specific measures. The National Board of Health and Welfare in 1929 described the problem in terms of a kind of innate "social parasitism":

"Those individuals, of which it will be certainly characterized by a common feature, namely a certain congenital or acquired working shyness and a resulting therefrom running tends to parasitize. This parasitism, however, shows a large, if one may so express it, adaptability and emerges, wherever and whenever society opens up, which prepares individuals to the illegal means and without work assimilate the fruits of others, labors." [11:62]

Measures to achieve an adaptation of these individuals were considered mostly futile, because their relation to other people to a large extent were determined by their family mentality and they often were considered to lack the psychological conditions for an adaptation to the current moral education and standards of behavior. Both biologically and socially these imaginaries were constituted as being a load factor of Swedish society [7].

Throughout the postwar period extensive reforms to the Roma have been conducted, in order to house the Roma in the Swedish welfare state construction. This political will includes transforming the image of the Roma from being regarded as vagrants to being socially handicapped $[11,12] \mathrm{It}$ 
was state that the Roma was "a poor and impoverished group in need of help to be able to adapt to modern life." [13] In line with a growing interest at EU level designed Government 2012 "a coordinated and long-term strategy for Roma inclusion 2012-2032" with the goal that when "the Rom is 20 years old in 2032 she or he should have equal opportunities in life as that of non-Roma." [1:10]

One of the important means mentioned when it comes to "lift Roma exclusion" [15:58] is the EU's structural funds. A survey of the social projects targeting Roma under the European Social Fund has shown a recurring rationality according to which the Rom still stands out as deviant and the need to adapt to a modern, responsible and equal Swedish normality [14]. Rationality of these projects thus comply broadly with Norma Montesinos and Ida Olsson Al Fakir's conclusion that "since the 1950s, the expanded Swedish government policy towards the Roma have tended to cement rather than changing the Roma's position as outsiders in the Swedish society." [13] A number of studies have shown how the Roma are still victims of discrimination. In the housing policies the Roma are denied housing for example because too many Roma already live in the region in question. In the judiciary, there is a widespread prejudice against Roma, including among prosecutors, lawyers and police [15-17].

In a study in Sweden on Roma experience of discrimination the whole $90 \%$ of respondents described Sweden to a large extent as a racist country [16]. A similar proportion described Sweden as partly or largely hostile to Roma. More than $60 \%$ also stated that during the past 2 years they had been called "Gipsy bastard" (zigenarjävel) or any other offensive, alluding to their Roma origin. According to a survey from the Swedish National Commission on anti-ziganism, 290 antiRoma hate crimes were reported in year 2014. The most common places where these crimes were notified was in public places and service points. Of the notifications made in 2013, only three percent were cleared up 2015 [16-18].

\section{Ana, the Non-Roma and the typical Roma}

It's not much of this persecution and discrimination history looming in Ana's story. Her Roma affiliation seems essentially thwarted. Ana's Roma-hood emerges mostly indirectly - as something she shies away from trying to hide. However, as there are some traces of bygone days of thinking and imagery in Ana's way to describe the Roma and the Roma situation, we have reason to come back to it in the following.

In Ana's story the Roma affiliation is a double anomaly distinct from both the Hungarian and Swedish. It is designed and treated as an anomaly both in Hungary and in Sweden. Living in Sweden has its own problems, but based on experiences of visiting relatives and friends in Hungary, she draws the conclusion that Sweden, as compared to Hungary, is a much more tolerant society: "compared to Hungary, it's totally different". Above all, she describes the situation of the Roma in Hungary as very precarious, "you can feel sorry for them, for those who go to work and contribute to the Hungarian society. They suffer and suffer from racism to an extreme. They kill them [the Roma] and they beat them, and afterwards they are exposed to a very extreme racism, I can say."

Ana describes consistently the Roma as They. They are not her. Even if she is not They, she feels sympathy for them. It's bad for them, she claims, as They are subjected to extreme stigmatization. According to Ana, the situation is completely different in Sweden. "It's much easier to be here. [...] It's so multicultural here in Sweden, so you don't feel it [the stigmatization] so much." At the same time, she describes a very different Sweden, where there is prejudice and discrimination - particularly towards Roma. When growing up, she was marked out and treated as being Romani: "I was the only girl in the entire school with a foreign background. [...] It was really hard to be in school [...]." It turned out to be harder to be accepted than she had expected.

"I spoke English in school as I didn't know any Swedish at all [...] I felt that, okay, now I'm in Sweden, now I can be as open as I wish to be, so I told a girl that my dad was Roma and so. Then she told me that I shouldn't tell anyone else in school. [...] So I didn't tell anyone else, for I was like okay, then I like to keep quiet about it. There, however, are of course those perhaps less well suburbs or what to say, villages and such so it may be that they are a little more... like 'now we will not have foreign here and so'. Thus they had in themselves not in mind that I was Hungarian, but I was just Roma."

Here she describes the challenge to position herself in relation to how people [in Sweden] imagine Roma people. Her strategy has been to avoid telling people about her Roma background. When she speaks about herself, she clearly distances herself from what she describes as "typical Roma people." "I'm not raised as a typical Roma girl, so to say. You can see if a person is Roma. But me, I don't think people can see that I'm Roma." She thus makes a distinction between "Roma" and "Roma people" - the typical Roma people and the few Roma people like herself.

Ana goes on talking about other situations, when she was ashamed that she had to be in the admiring glances. Ambient constant watching responses forcing her, like many other Roma [19], to develop different strategies - to hide, to avoid talking about her affiliation and to position herself as nonRoma [20,21]. The desire to escape ambient judgmental looks is familiar with Fanon's description of the colonized person's self-image. 
"I slip into corners, and my long antennae pick up the catch-phrases strewn over the surface of things - nigger underwear smells of nigger - nigger teeth are white nigger feet are big - the nigger's barrel chest - I slip into corners, I remain silent, I strive for anonymity, for invisibility. Look, I will accept the lot, as long as no one notices me! [...] Shame. Shame and self-contempt. Nausea. When people like me, they tell me it is in spite of my color. When they dislike me, they point out that it is not because of my color. Either way, I am locked into the infernal circle." [22]

The essential difference between Fanon's colonized negro and Ana is that she can pass as a non-Roma, if she is not self-disclosing her Roma origin. Negro skin color is black and - on the contrary - always visible. There is no way to get rid of it, other than to annihilate itself - and become white. The same applies to the "typical" Roma, whose appearance and manner of dress makes them easy to identify with the naked eye. Just because Ana has chosen to never talk about her Roma origin. She does not want to risk ending up in a situation where everyone in the environment observes and identifies her as Rom and interprets everything she does from her Roma-hood. She has chosen to be non-Roma.

Based on the position of non-Roma, Ana chisels herself away from being the typical Roma. When she describes the typical Roma person, a well-established stereotype emerges: the self-excluded, passive Roma, who does not wish to work and who uses the system: "Most of the time, among Roma people, they use the Swedish system. [...] They do not like to work. And that's how it has been since generations." It is again the image of the Roma that parasites that is portrayed [23]. Ana describes an almost ancestral mentality that in itself helps to restore Romas' existence in the margins of society [14]. In Ana's story she describes 'Roma' as a single ethno-cultural collective. The picture is rough and homogenizing. By describing herself as an atypical Roma she emerges as a free individual, while they [the Roma] appear to be more dependent and deeply rooted in discrimination.

"It's so deep inside them, since generations back [...] your parents' way of life and their view on society influence you so much, how they live, but it could also be due to them having been through so much discrimination and such from society. [...] They have discriminated [against] me because I'm Roma, so why should I contribute to anything?"

In relation to this characterization of the typical Roma person, she positions herself as being well-adapted to Swedish society. "I feel that I adapt quite well to society. I do not think it is so different from, for example, when I go out on the town in Sweden or how I am in town as well, so I do not think there is any difference at all." As a Hungarian, she feels not particularly different, because she does not behave particularly different or look particularly different. Her biggest problem though, is to be related to those who she does not wish to adapt.

'I'm bunched together with those who do not wish to live as Swedish citizens, and it's I who have to suffer from it, and I don't want my children to suffer from it."

In her understanding of citizenship, the citizen is characterized in a particular way as bearer of rights and duties. Even if she herself is not yet fully seen as Swedish, she is still a Swedish citizen, and as such she is a bearer of certain rights. As a citizen it is also, she points out, a question of following laws and regulations, ie to fulfil one's duties: The citizen is chiseled out as representing what the Roma is not - as contributing to the society by training and acquiring work.

"It's important for me as a Swedish citizen to have rights; that I have the same rights as a Swede has, who has Swedish origin. That means a lot, and I believe everyone should enjoy the same rights, no matter from where one comes, and if one comes to Sweden and becomes a Swedish citizen you should have the same rights, but at the same time follow the Swedish laws. If you live in the Swedish society, you follow their laws, and then you are granted the same rights. There are some who use the Swedish society, who wish to have the same rights as a Swede does, at the same time, as they do not really follow the laws."

Here, Ana construes belonging through difference. She does not belong to the category 'of Swedish origin', or the category of those who use the Swedish system. She is somewhere in the middle - neither one nor the other; neither "We" nor "Them". She describes herself as belonging to the Swedish society by distancing herself from being one of "Them" - those who use the system - but not based on the same principle as being "We" - Swedes with a Swedish origin. Thus, Ana construes Roma and Swedes as rather homogenous, ethno-cultural groups, with herself freely negotiating between them, in an in-between position. The problem is, once again, that some people demand their rights as citizens without fulfilling their duties. Thus, she argues that people immigrating to Sweden need to "pitch in more", show gratitude, and earn their citizens' rights.

"I really believe that they should pitch in more than a Swede, because a Swede is always a Swede. [...] Show gratitude, thank you so much for letting me live here and be part of the Swedish society." 
For this reason, she can also understand how it is that more and more have chosen to vote for a xenophobic party Sweden Democrats, who built much of his popularity and his success that in many respects to highlight the multicultural society problems and to portray party as the restoration of a lost welfare state, a Sweden that was still Sweden.

"They have no right to what is absolutely not, but yes, I can understand that they think that why should my country to receive you and you will be part of my society and my society will support you and your family and you should as well go and do criminal things, and so on and not, absolutely not contribute to society? So I can understand that the mind arises of Swedes then."

In Ana's story there is a duality in the way of relating to the multicultural Sweden: on the one hand, the diversity which makes it easier for her to stay in Sweden than for example in Hungary, but on the other hand transformed Sweden through an increasing diversity of Swedes which are not Swedes.

"Sweden is a multicultural society. Sometimes I even think that it shouldn't be called Sweden anymore, because you look so to speak, barely Swedes, especially in the city."

Ana seems to be eternally grateful that she is allowed to stay in Sweden and be a part of Swedish society. She is also really keen to do the right thing. The rationality is the same as the one that Fanon describes in the Jean Veneuse, the main character in the novel Un Homme pareil aux autres: a black man, born in the Antilles but long accommodation in Bordeaux, "He accepts the drinks, but he buys others in return. He does not wish to be obligated to anyone. For if he does not buy back, he is a nigger, as ungrateful as all the others." [1:58] As Veneuse, what Ana wants is not to be seen as one of them, the ingrates, those who do not even consider themselves to have a debt to repay. She would rather have earned their rights - and she wants the world to know it.

In Ana's story, there is a graded citizenship emerging in which citizens' rights are directly linked to belonging to the national society. The relationship between being "Swedish" and being an "immigrant" is one-directional and hierarchical. "A Swede is always a Swede", and always has the right to put demands on those who have immigrated, while the reverse is not allowed [24]. In relation to the previously mentioned pressure of "paying back" what one has received, Ana's "gratefulness" is also oriented toward the future in Sweden.

"I want to help people ... I want to work with people and I want to help them and contribute to society in the way that I feel that I'm helping them."
Besides from performing a kind of reactive response of gratefulness, or paying back, the distinction between we and them appears, where Ana wants to be part of "us", and help "them" to be the same as "us". The entrance ticket to the society is that of paying back, which is pulled forth in terms of helping and care-taking, in order to show her gratefulness toward (the Swedish) society. To help other people is to do the right thing. And this is what she wants to help them to do and to want-to-do. Ana wants other people to follow her good example in developing this helping desire in the future.

"During my 24 years I have always been a person who has listened. I am not the kind person, kind of, who goes and asks people about things, but someone that people come to and like talking to about their worries, and I love it, I like to listen to others' troubles and like to comment and help with words and my experience, and linking it to their problems, and I like to say to them that this is how I did, or how my parents did, you may be able to test it, and kind of do so."

She finds her experiences and desires to be exemplary also for others: do like me, follow me. The future, as portrayed by her, is a kind of return to a vanished Sweden, a pure and ordering place in the past, where Sweden was still Sweden. Ironically, it was precisely this order of sincerity and ideals that permeated people like her historically and that keeps her locked out today. Yet she chooses to re-establish this tragic pattern - and wants to get others to follow in her footsteps.

\section{Europe and the (un)freedom of movement}

If we leave Ana's story for a while, in order to cast light on Europe as a context in recent years, the Roma have once again come to the fore in public debate, as a result of an increasingly visible presence of poor European migrants in Sweden and elsewhere, primarily from Eastern Europe. Put briefly, within Europe there is an actualized and central issue of the Roma and their presence. The testimonies of how Roma in the new Member States of the enlarged European Union have been persecuted and discriminated in all arenas of society in present times - education, labor and housing, politics and the judiciary - are numerous [21,23,25].

Ana's story, and her constantly ongoing negotiations for membership in a multiethnic Sweden reflects in some sense the ongoing negotiations on citizenship conducted in light of the situation of Roma EU migrants. Her story may serve as a reminder that the precarious situation of the Roma in Europe can be seen as an illustrative example of paradoxes of citizenship in contemporary Europe [26]: As the Roma in Europe, she is on one hand a fully-fledged citizen, with all the formal rights that citizenship is given. On the other hand, she does not 
have substantive equal rights, including the right to move freely within the EU's borders [9].

If we recall a recent event in France in 2010, similar arguments are activated in Ana's story as those reverberating in this event, where escalating conflicts between Roma and police in camps in Grenoble and Saint Aignan led the French government to take a decision on expelling all Roma from France due to alleged "sources of smuggling, shocking living conditions, prostitution and crime." [27] The French expulsion illustrates clearly the EU European citizen making paradox. The Roma who were deported from France were formally European citizens, with the rights it guarantees - including the right of free movement. Yet, they were denied the right to move within the EU's borders. The formal right to free movement, in other words, substantially, a privilege reserved for certain - not Roma [28,29].

In 2015, the Swedish Prime Minister Stefan Löfvén signaled in many respects similar eviction of Roma in Sweden. Hundreds of migrants from Romania and Bulgaria, many of whom are Roma, was evicted from a vacant lot in the district Sorgenfri in the fourth biggest city of Sweden, Malmö, where they camped. The eviction attracted considerable media attention. When the Prime Minister commented on the incident, he did it by emphasizing that EU migrants (themselves) are bestowed their responsibility, not Sweden:

"They may come here, of course, and be here for a while, but in the long run it is their own countries must take responsibility for that they get work, education, and housing in his country. This is not something that Swedens have responsibility for."1

The message is that the migrants' welfare is not the welfare state Sweden's responsibility. While the statement reflects the tone of a contemporary migration policy debate, it expresses ideas that are familiar from the history. Both the idea of sending clear signals to avoid more traveling migrants and the idea of welfare on a voluntary basis have occurred far earlier in history. In addition, it feeds on an underlying vision of Roma that is familiar from history - the Roma as deviant elements, that profit on the spirit of others' benevolence, and whose way of life goes on from generation to generation. Out of Ana's story, Sweden's and not least Europe's, we wish to make some concluding remarks on the situation of today and tomorrow.

\section{Recognition and the future - concluding remarks}

This article has focused on belonging and participation in society - the Swedish and the European. Based on a story

\footnotetext{
${ }^{1}$ The daily national newspaper Expressen, quoting the Swedish Prime Minister, 3 Sept 2015
}

from a young Roma woman, Ana, who migrated to Sweden from Hungary, the article focuses on the situation of Roma in Sweden, a category that has long challenged conventional notions of belonging, rights and obligations, and in various respects have been forced to live in the fringes of (Swedish as well as European) society. The overall addressing of Ana's story is the burning question of who actually should belong to society and under what conditions - and who will be left out? At the fore of our concern stands the issue of recognition. Who will be recognized as a fully-fledged citizen? And who is forced - conversely - to live life as non-recognized, and see her- or himself as non-recognized, in the eyes of the surrounding?

Ana's story of how she came to Sweden and how she has tried to find a bearing with life and become part of a Swedish society addresses these pressing questions of belonging. It can be seen as a story of belonging but simultaneously not belonging, not to be recognized for who one is, while not recognizing oneself and vice versa. The story shows some of the internal stresses that can arise in the aftermath of migration (policy) in Sweden, and moreover in Europe. It highlights in some sense a kind of double paradox when it comes to citizenship in present times, of international migration: As a Swedish citizen she belongs - formally - to society, but as Ana describes it she still does not fully belong to this society, based on who she is namely Roma. Moreover, and at the same time, put in light of the EU European migration policy she personifies - exactly by being a Roma - the ideal EU citizen (non-territorial by definition). But at the same time she is seen as an anomaly. Her Roma-hood makes her, in other words, doubly different.

Looking more profoundly into the logic of Ana's story, it seems to be at stake that she wants to escape from who she is, by hiding and appear as non-Roma through her action-taking towards others, ie by doing the right thing, in a way in which she - in her own view - becomes non-Roma. The hope is that this gives her full access to Swedish society. Last but not least, she also encourages others to follow her example, ie to also do their part as a means of being included in society. However, the somewhat tragic moral of the story is that Ana's will to inclusion is doomed to fail. No matter what she does, she may even attempt to annihilate herself, escape her Roma-hood, she still remains the Other. Again, a parallel to Fanon, "my unreason was countered with reason; my reason with 'real reason'. Every hand was a losing hand for me." [1:101] Ana remains the abnormal body that defiles the otherwise "pure" Swedish societal body - and, by extension, the European societal body. Whether she wants to or not, she is being denied access to society as a full member of the societal community.

Taking on Ana's tragic story, we would argue that it unfolds not only an individual destiny but also the destiny of Europe. The Roma are in fact part of a European society that they are still not fully allowed to be part of. Not even if Ana obliterates herself, thus becoming part of the society, she is allowed to 
belong to the same. Her Roma-hood makes her, in other words, doubly different. Ana's story addresses crucial questions concerning European citizenship and the future of Europe: who should really be included in the European community of citizens, on what conditions, and who should be left out? These particular questions are at the very centre of the political debate in Europe today.

On one hand, throughout Europe strong voices have claimed the "death of multiculturalism", and put forward demands for the development of new forms of ethno-culturally graduated citizenship, not least in Sweden.[30] On the other hand, in Sweden as well as in other European countries, claims have been made for the development of a new and more inclusive societal community which expands the rights of citizens by accommodating those who have previously been excluded, among those also the Roma (for instance as emphasized in the strategy on Roma inclusion initiated by the European Community in 2011) [31, 32].

Focusing on the Roma and the notion of recognition, what is at stake in Ana's story is that recognition as a matter of belonging to equal citizenship in society is not something that happens by itself. It is rather the result of a long struggle, where those outside challenge the situation and require new forms of citizenship, beyond the predefined templates, distinctions and exclusionary bounds. The requirements for such struggle have not at least been put forward by the European Roma, which for centuries have not been recognized as citizens or as fellow human beings. The recognition of the Roma can be realized only "when they begin to recognize and challenge the neocolonial relationships they encounter and thereby empower themselves in the diversity of contexts that make up their daily lives (schools, workplaces, government agencies and other institutions)." [31]

Such negotiations are also played out at the best in contemporary Europe, where also the Roma themselves have been actively involved in defining both problems and solutions. The claims are several. Some of them claim the collective rights as part of a non-territorial Romani nation within the EU borders [26], while others of Them claim to be part of a European We, with legitimate claims to belong to the 'inside' with all the substantive rights it entails. They hereby request to be recognized as belonging in a way reminiscent of how Fanon in the early 1950s demanded to be recognized as black and Frenchman: "I am a Frenchman. I am interested in French culture, French civilization, French people. We refuse to be considered 'outsiders', we have full part in the French drama.'"[1:157]

Concerning the future of Europe and European citizenship, there are several scenarios. The one that perhaps appears as the most prevalent in Europe of today is that defined in terms of ethno-cultural sameness or homogeneity, by the drawing of boundaries between the core and the peripheries within Europe as well as between Europe and its "outside".
Referring to Fanon, this scenario could be described as reactive, based on the continuous non-recognition of the Roma as European citizens. However, there are other scenarios. What is crucial, is creating a future Europe as another place, where either yesterday or contemporary times are being played out as prevailing; ie as a place created by people who act, not just react. Here, the pressing question is still, following Fanon: "To educate man to be actional, preserving in all his relations respect for the basic values that constitute a human world, is the prime task of him who, having taking thought, prepares to act." What is at stake, thus, is the possibility of developing a future Europe actively recognizing both the formal and substantive rights of the Roma, grounded on the notion that "I am not merely here-and-now, sealed into thingness. I am for somewhere else and for something else." [1:73, 170]

Contestations and negotiations of citizenship are constantly made, in quite undramatic, ordinary ways in people's everyday lives. However, as shown not least by recent developments in peripheral suburban areas in Sweden and other European countries, such contestations may also take the form of collective actions, challenging current notions of citizenship in contemporary multi-ethnic Europe, indicating the struggle for equal citizenship rights [33].

Which scenario that eventually will guide the future of Europe is - of course - a matter of politics, political contestations and the claiming of rights. Violent or not, such contestations point in other directions for the future of European citizenship, whose outcomes are anything other than decided beforehand.

Open Access This article is distributed under the terms of the Creative Commons Attribution 4.0 International License (http:// creativecommons.org/licenses/by/4.0/), which permits unrestricted use, distribution, and reproduction in any medium, provided you give appropriate credit to the original author(s) and the source, provide a link to the Creative Commons license, and indicate if changes were made.

\section{References}

1. Olson M (2012) The European 'We'. Stud Philos Educ 3(1):77-89

2. Månsson N (2010) Låt skillnaden vara. Utbildning Demokrati 19(3):39-56

3. Sjögren D (2010) Den säkra zonen. Dissertation, Umeå universitet

4. Malkki LH (1997) Purity and exile. University of Chicago Press, Chicago

5. Olson M (2009) Democratic citizenship: a conditioned apprenticeship. J Soc Sci Educ 8(4):75-80. doi:10.4119/UNIBI/jssev8-i4-1103

6. Svanberg I, Tydén M (1992) Tusen år av invandring. Natur \& Kultur, Stockholm

7. Catomeris C (2004) Det ohyggliga arvet. Ordfront, Stockholm

8. de Genova N (2016) The 'European' question. In: Amelina A et al (eds) An Anthology of Migration and Social Transformation. Springer, New York 
9. Olson M (2012) Citizenship education without citizenship? In: Hedke R, Zimenkova T (eds) Education for Civic and Political Participation. Routledge, London, pp 155-170

10. Selling J (2013) Svensk antiziganism. Sekel, Lund

11. Montesino Parra N (2002) Zigenarfrågan. Dissertation, Lunds universitet

12. Montesino Parra N (2012) Social disability. Int J Migr Health Soc Care 8(3):134-145

13. Montesino Parra N, Ohlsson Al Fakir I (2015) The prolonged inclusion of Roma groups in Swedish society. Soc Incl 3:126-136

14. Vesterberg V (2016) Exploring misery discourses. Eur J Res Educ Learn Adults 7(1):25-40

15. Granér R (2004) Patrullerande polisers yrkeskultur. Dissertation Lunds universitet

16. du Rées H (2006) Åklagares och advokaters syn på likabehandling $\mathrm{i}$ domstolen. In: du Rées H \& Sarnecki J (eds) Är rättvisan rättvis?, SOU 2006:30 [Swedish Governmental Commission on power, integration and structural discrimination], Stockholm

17. The Swedish National Commission on EU-Migrants (2016) SOU 2016: 6. Framtid sökes - slutredovisning från den nationella samordnaren för utsatta EU-medborgare. [Government report from the national coordinator on vulnerable EU citizens], Stockholm

18. de los Reyes P, Schierup U, Alund A, Kings L (2014) Reading the Stockholm riots. Race Class 55(3):1-2

19. The Swedish National Commission against anti-ziganism (2015) Registrering av romer. Kommissionen mot anti-ziganism. [Government report], Stockholm

20. de los Reyes P (2009) Unga romers situation. Ungdomsstyrelsen, Stockholm

21. The European Commission against Racism and Intolerance (ECRI) (2015) ECRI Report on Hungary. Council of Europe, Strasbourg
22. Fanon F (2008) [1952] Black skin, white masks. Pluto Press, London

23. Pusca A (ed) (2012) Roma in Europe. International Debate Education Association, New York

24. Dahlstedt M, Hertzberg F (2007) Democracy the Swedish way? Scand Polit Stud 30(2):175-203

25. Human Rights Watch (1996) Rights denied. Human Rights Watch, New York

26. Isin EF (ed) (2012) Citizens without frontiers. Continuum, London

27. Malecki M (2014) The new Europe. In: Walton-Roberts M, Hennebry $\mathrm{J}$ (eds) Territoriality and migration in the E.U. neighbourhood. Springer, Dordrecht, pp 111-124

28. Carrera $\mathrm{S}$ (2014) The framing of the Roma as abnormal EU citizens. In: Guild E, Gortázar Rotaeche CJ, Kostakopoulou D (eds) The reconceptualization of European Union citizenship. Brill Nijhoff, Leiden

29. Chatty M (2015) Migranternas medborgarskap. Dissertation, Örebro universitet

30. European Commission (2011) An EU framework for national Roma strategies up to 2020. $\operatorname{COM}(2011) / 171$

31. Trehan N, Kóczé A (2009) Racism, (neo-)colonialism and social justice. In: Huggan G, Law I (eds) Racism, postcolonialism, Europe. Liverpool University Press, Liverpool

32. Dahlstedt M, Neergaard A (eds) (2015) International migration and ethnic relations. Routledge, London

33. Skr 2011/12:56 (2011) En samordnad och långsiktig strategi för romsk inkludering 2012-2032. (engl: Government communication 2011/12:56. A coordinated long-term strategy for Roma Skr. Inclusion 2012-2032) [Government Report, on coordination and sustainable strategies for Roma inclusion], Stockholm 